\title{
Emotion, voice and agency: Exploring the written discourses of some township women in South Africa
}

Charlyn Dyers, Meggan Williams and Tatum Barthus

\begin{abstract}
:
This paper is an analysis of the discourses and attitudes that emerged from a set of daily journals kept by a particular group of township women during a training course for domestic workers in South Africa. The principal aim of the paper is to examine the ways in which the women express emotion, voice, and agency through the act of writing and reflecting on their experiences during the training course. A secondary aim is to uncover those recurrent discourses and attitudes that either empower or disempower these women from becoming effective agents capable of challenging their positions in their families and society. The theoretical and conceptual framework for this study draws on Appraisal Theory and studies on voice, agency and identity.
\end{abstract}

\section{Introduction}

Post-apartheid South Africa is engaged in a number of macro-discourses relating to current and future socio-political developments in the country. However, the microdiscourses of citizens at grassroots level are surely just as important to determine the key issues affecting the lives of ordinary people. This paper uses the Appraisal framework of White (1998, 2000), Martin (1997, 2000), Martin and Rose (2007), and others in an examination of the discourses present in the personal journals of a group of unemployed women from a peripheral Cape Town township. According to White's Appraisal homepage (White, n.d.), the Appraisal framework is 'a particular approach to exploring, describing and explaining the way language is used to evaluate, to adopt stances, to construct textual personas and to manage interpersonal positionings and relationships'.

The women who wrote the journals were selected by a university centre to attend a threeweek training course in domestic service in order to provide them with a qualification in this field, which would improve their employment prospects. Every day, they were transported out of their township to the training centre in a major university town approximately $20 \mathrm{~km}$ away. In their journals, they reflected on the experience of leaving the township daily to attend the course in a more pleasant environment, leaving behind their situations of poverty and male dominance, in most cases, their hopes for the future and their beliefs or not in how the experience might enrich their lives.

The paper poses the following questions: 
- In what ways do these women express emotion, voice, and agency through the act of writing and reflection on their experiences during the training course?

- Which recurrent discourses and attitudes appear to empower these women to or disempower them from becoming effective agents capable of challenging their positions in their families and society?

In the following section, we situate this paper within the context of the larger research project of which it formed a part.

\section{Background}

The study on which this paper is based formed the starting point of larger NRF-funded project entitled 'Township women's discourses and literacies'. The project focuses on the transportability of linguistic and literacy resources in a conception of literacy as a mobile resource in 'a township of migrants' (Dyers, 2008). It also examines how these linguistic resources can be used as tools of empowerment in relation to all the societal structures (such as family, community and local government) people need to negotiate in order to become more powerful agents of their own transformation into full participatory citizenship, as described by Stroud (2009) and Sutton (2008). We believe that studying the discourses of marginalised, previously-silenced communities in post-apartheid South Africa is of importance precisely because such micro-discourses reveal the real issues ordinary citizens grapple with. At the same time, it also has the potential to show whether people are taking on their roles as active, participatory citizens in this relatively new democracy.

It is no coincidence that we decided to focus on women for this project. The majority of women in South Africa have been doubly disadvantaged, both by the apartheid system, which severely damaged both the physical and emotional security of these women, and by a paternalistic society, which tried to keep women in perpetual subjugation to men. In the new South Africa, despite all the constitutional imperatives which guarantee freedom and equality for all, women continue to battle many obstacles of which poverty is a central component. Weiss (2004: 49) captures the essence of the condition of black and coloured women in post-apartheid South Africa which '... include the trauma of the colonial past and apartheid with its aftermath; lack of education and vast poverty; traditional customs such as female circumcision ....

Another important aspect of this project is identity, which, according to Williams (2010: 131), is 'socially constructed and constituted'. In the context of this paper, we can see a clear link between the different discourses of the women in our study and their sense of their own identities. Apart from sharing with many women from other ethnic groups in South Africa a common identity of being disadvantaged, these women also share the identity of being coloured and mainly Afrikaans speaking. The coloured people of South Africa are the descendants of unions between people of different races. Some are direct descendants of South Africa's indigenous Khoi and San people, while others are descended from political 
captives and other victims of the colonial era brought to South Africa as slaves (Dyers, 2008). Despite the negative connotations attached to the term 'coloured' as a form of racial classification (Dyers, 2004), we make use of this term throughout the paper as there are currently no acceptable alternatives.

Language is a key indicator of identity, and the South African 'coloured identity' is often attached to the language Afrikaans as principal home language, as was the case with the majority of these women. However, there are significant differences between knowing and speaking a language and actually writing it. These women mainly used Afrikaans to communicate orally but, as our data reveals, their writing revealed a range of proficiencies as well as practices like blending in features from other languages. With reference to the distribution of Afrikaans in the greater Cape Town area, Van Der Merwe and Van der Merwe (2006: 68) write: 'The spatial distribution of Afrikaans speakers is heavily concentrated in three wards, namely Blue Downs, Mitchells Plain and the Cape Town ward, where $56 \%$ of the city's Afrikaans population was accommodated.' The Blue Downs ward incorporates the township housing the women in our study.

Where people live, whether by choice or forced by circumstances, naturally also has a significant impact on their socio-cultural identities. Currently, the majority of black and coloured South Africans continue to live in townships on the periphery of major cities or in impoverished rural settings, dependent either on subsistence farming, employment in agriculture, or related industries. Unemployment is unacceptably high, particularly among the young (Statistics South Africa, 2011). The township in which the women in our study lived, is a 12-year-old, low-income housing initiative on the periphery of Cape Town known as Wesbank. This is a developing community that was established in 1999, following the country's first democratic elections in 1994 which brought an end to white rule and the rigid separation of races known as apartheid. The formal development of Wesbank brought together people from mainly rural areas and of different races to co-habit, learn and work together in one of the first racially mixed housing developments in the Western Cape after the end of apartheid. Moola (2002) as well as Achmat and Losch (2002) documented how the Provincial Administration of the Western Cape (PAWC) decided in September 1995 to earmark Wesbank as an area to which minimum income/'maximum subsidy' families could be relocated. This was their response to dealing with the growing crisis in housing provision to the escalating influx of people from rural areas into urban Cape Town after the end of apartheid.

Blommaert et al. (2005: 4) state that the houses in Wesbank 'are uniform and excessively simple in structure - people call them "matchbox houses". Joncker and Newton (2004: 113-118), in Blommaert et al. (2005: 3), contend that "Wesbank is by all standards a peripheral community, isolated from neighbouring communities and plagued by a variety of social and economic difficulties'. Wesbank can also be described as a hybrid community characterised by the fact that black, coloured and (some) white people are living in the same community (Joncker \& Newton, 2004). 


\section{The data}

As was noted in our introduction, this qualitative research study used the Appraisal Theory framework (discussed below) to analyse the journals of our respondents - a group of 13 unemployed, coloured, Afrikaans-speaking women attending a training course to become qualified domestic workers. These women were part of a group of 25 women selected to do the training based on their limited yet reasonable level of literacy (most had completed Grades 5 to 7 of primary school), the amount of time they had on their hands, and their willingness and motivation to attend the course. As a result of the language distribution of the group as a whole, the women were taught in two groups - one group, made up of 17 coloured women, was taught in Afrikaans, while the other group, made up of eight black women, who were mainly isiXhosa speaking, was taught in English as the particular centre where the course took place had no isiXhosa-speaking facilitator. The discourses of the latter group will be the subject of a second paper.

A module aimed to improve the spoken and written communication skills of the course participants formed part of the course. Each lesson in communication skills started with 10 minutes of writing their daily journal entries. The initial aim of the journal-writing sessions was quite simply to see whether the women's writing skills were improving as a result of doing the module. The women provided their written permission at the end of the course for the use of their journals as research tools, on condition that their names and personal details were not revealed. It would appear that while some women started the course with limited literacy skills, the course may indeed have helped to develop these skills. This was evident from their improved handwriting, language use, as well as the structure and increased length of the entries as the course progressed.

The journals analysed in this study can also be called 'participant diaries' (Jones et al., 2000) as these women focused on both the cognitive and affective aspects of participating in a training course. Keeping a daily journal was one way in which the women could be active, reflecting research participants instead of passive research subjects. As Jones et al. (2000: 319) note: 'the participant diary genre lends itself particularly well to the study of the action and interaction of people's day to day lives and the ways in which spoken and written languages are intertwined in different types of literacy events'.

Having data as personal as journals/participant diaries to work with enabled us to 'hear' each woman's voice, even the voices of those who wrote very little. According to Blommaert (2005: 4), "Voice stands for the way in which people manage to make themselves understood or fail to do so. In doing so they have to draw upon and deploy discursive means which they have at their disposal, and they have to use them in contexts that are specified to conditions of use'. We are in full agreement with Blommaert (2005: 5) when he further contends that voice 'is the issue that defines linguistic inequality (hence, many other forms of inequality) in contemporary societies. An analysis of voice is an analysis of power effects'. Finding their voice and expressing it in writing may not be enough, however, as it does not necessarily signal an ability to move past locations in passivity, but it is an essential consideration in extending views about agency - what 
people are not only capable of doing within the circumstances in which they find themselves, but what they are willing to do. Labelle (2011: 174) sees agency as the type of control individuals exercise over the ways in which they present themselves to the world and contends that it depends on 'the society they live in (and) the way in which their language encodes social categories'. Hernandez-Zamora (2010: 9) emphasises that the development of agency is inseparable from developing people's literacy and education levels, as 'their crucial role is to enable us to think and speak for ourselves'.

In identifying the main discourses present in the journals of our respondents, we were guided by the presence of particular emotion words. Pavlenko $(2005,2011)$ and others have done valuable research into the link between emotion and cognition and areas such as inner speech, language, thought, and autobiographical memory. Altarriba (2005) has demonstrated the ways in which memory is stimulated by particular emotion words such as 'love', 'envy', 'hate', and 'jealousy'. For many of the women, the journals became a kind of confessional in which they were quite open about their daily experiences and the emotions aroused by these experiences. However, this act of writing could potentially place them in a (symbolic) space (Baynham \& De Fina, 2005: 259) that left them exposed, vulnerable, and possibly disempowered as they revealed the conditions of their lives. The research team, however, found the women willing to 'open up', particularly as they were performing the act of writing in the confines of a classroom in the pleasant environment of the training centre with its sympathetic facilitators. They had therefore been moved, albeit for a short period, from a disadvantaged space to a kinder, more privileged space which may have disposed them to unburden themselves in their journals.

\section{Appraisal Theory}

Appraisal Theory was initially developed as a branch of Systemic Functional Linguistics (SFL) by Australian academics belonging to the 'Sydney School', namely, Martin, Rose, White, Christie, Coffin, Rothery and others (White, 2000). These researchers have explored the literacy requirements of the discourses of science, technology, the media, history, English literature studies, geography, and the visual arts. Martin and Rose (2007: 17) offer the view about Appraisal being concerned with evaluation - 'the kinds of attitudes that are negotiated in a text, the strength of the feelings involved and the ways in which values are sourced and readers aligned'. These meanings, they argue, 'realize variations in the tenor of social interactions enacted in a text' (Martin \& Rose, 2007: 17).

According to White (2000: 1), Appraisal Theory is concerned with the linguistic resources ... by which ... speakers come to express, negotiate and naturalise particular inter-subjective and ultimately ideological positions'. In other words:

APPRAISAL is a system of interpersonal meanings. We use the resources of APPRAISAL for negotiating our social relationships, by telling our listeners or readers how we feel about things and people (in a word, what our attitudes are) (Martin \& Rose, 2007: 26; emphasis added). 
Martin and Rose (2007: 25) argue that Appraisal is 'concerned with evaluation - the kinds of attitudes that are negotiated in a text, the strength of the feelings involved and the ways in which values are sourced and readers aligned'. In addition, attitudinal positionings or relationships are always occurring through a process of negotiation due to the interactive or dialogic nature of discourse (Martin \& Rose, 2007: 26). Discourses like those explored in our respondents' journals therefore provide indications or expressions of attitude. White (n.d.), in his Appraisal website homepage, writes as follows about analysing attitude:

(A)ttitudinal meanings are better seen as carried by utterances, by complete propositions than by individual words although in some instances it IS possible to point to individual lexical items as carrying attitudinal assessment. The unit of analysis, then, is the proposition or proposal, or a sequence of interconnected propositions or proposals, analysed in the context of the larger text in which they operate.

There are three main ways in which attitude is expressed, namely, affect, judgement and appreciation. 'Affect' refers to the ways in which people express their feelings in discourse to indicate positive or negative feelings in a direct or implied manner (Martin \& Rose, 2007: 29). 'Judgement', on the other hand, relates to evaluations of people's character or behaviour. Judgement can be expressed on a personal level to indicate admiration or criticism of people's behaviour, and it can also occur on a moral level to suggest praise or condemnation (Martin \& Rose, 2007: 32). 'Appreciation' can be identified by looking at the manner in which the value of things is construed through language (Martin \& Rose, 2007: 37).

Attitudes can also be amplified through graduation devices that highlight force or focus in a speaker's statement. 'Force' relates to the use of words that intensify an expressed attitude such as 'very' or 'extremely'. 'Focus' concerns the use of resources that make something that is inherently non-gradable gradable to sharpen or soften categories or concepts (Martin \& Rose, 2007: 47).

Compare, for example, the sharpened focus of 'at precisely 12h30' compared to the softening effect of 'around 12h3o'.

Beyond attitudinal positionings with their negative or positive assessments of people or things, for example, there is also what White (2000) terms 'dialogistic positioning' or 'engagement'. 'Engagement covers resources that introduce additional voices into a discourse via projection, modalisation, or concession; the key choice here is one voice (monogloss) or more than one voice (heterogloss)' (Martin \& Rose, 2007: 59). White (2000) lists the following key engagement resources present in discourse: disclaimers, proclamations, probabilisations, and attributes. A subtype of dialogistic positioning is 'intertextual positioning', which, at its most basic, is the use of the words or thoughts of another by a speaker or writer. 
What we found useful in relation to 'engagement' was to use an adaptation of this form of Appraisal as suggested by Slemming (2010), a fellow researcher on the larger research project. Like her, we also sought to identify traces of active engagement in terms of the women's expressions of the degree to which they were engaging beyond the conceptual and perceptual to the participative, that is, where we saw evidence in what they said about what they were doing that illustrated a form of active, responsibility-taking behaviour that could be considered transformative and empowering on personal and interpersonal levels.

\section{Appraisal analysis}

A discourse analysis of the journals revealed four major discourses present in the writings of our respondents:

- faith in God

- being trapped in the poverty cycle

- feeling trapped by their personal circumstances

- a desire for greater independence.

In these four discursive themes, we found a strong relationship between the ways in which these women expressed emotion and the ways in which their individual voices and agency came through. Some women, especially those affected by domestic violence, appeared to be emotionally overwhelmed by their situations and were greatly in need of support to overcome their difficulties. Others appeared to be able to transcend these difficulties by persevering with the course and combating negative emotions with more positive ones.

The presence of these discourses pointed to the particular value systems of the women as well as the different assumptions they made about the value and belief systems of their respective intended audiences. Our Appraisal analysis provides more evidence of these values and beliefs and is done, firstly, according to the three subcategories of attitude: affect (emotion), judgement (ethics) and appreciation (aesthetics). Secondly, we analyse the degree of engagement and dialogistic positioning in the journals.

In this section, numbers (W1, W2, and so on) have been assigned to the women to protect their identities. We have not made any corrections to the original texts in Afrikaans as written by the women, but provide translations into English.

\section{Attitude analysis}

In line with the affect examples on White's Appraisal website/affect, the examples provided in Table 1 indicate affectual positioning through the following indicators:

- verbs of emotion such as 'is dankbaar' (am thankful) and 'is wonderlik' (is wonderful)

- adverbs such as 'baie afkraak' (often belittles) and 'so swaar' (that's how badly)

- adjectives of emotion such as 'baie ongelukkig' (very sad) 
- nominalisation (the turning of verbs and adjectives into nouns) such as 'die seer in my hart' (the pain in my heart).

In addition, affect can either be positive or negative as well as authorial (first person) or non-authorial (second and third person). Authorial affect occurs when people take responsibility for their response to other people, situations, or things, whereas nonauthorial affect occurs when the emotions of others are described. 'Intertextual attribution' is the inclusion of the 'words, observations, beliefs and viewpoints of other speakers/writers' (White, n.d.).

Table 1: Examples of affect

\begin{tabular}{|c|c|}
\hline $\begin{array}{l}\text { W1: Ek is dankbaar vir God vir nog 'n dag om hier te kan wees. [I } \\
\text { am thankful to God that I can be here another day.] }\end{array}$ & Positive authorial affect \\
\hline $\begin{array}{l}\text { W2: Ai die Here is wonderlik ek kan net vir die Here dankie sê dat } \\
\text { hy my tot hier gestuur het. [Oh the Lord is wonderful; I can only } \\
\text { thank the Lord for sending me here.] }\end{array}$ & $\begin{array}{l}\text { Positive authorial affect plus intertextual } \\
\text { attribution to God. }\end{array}$ \\
\hline $\begin{array}{l}\text { W5: Deur die seer in my hart wat ek het, sê ek dankie vir God } \\
\text { vir hierdie dag vir my lewe vir my kinders wat na my kan opkyk. } \\
\text { My ma se suster is vermoor. En ek wil God nie bevraagteken. Ek } \\
\text { weet dat hy my nooit 'n kruis sal gee wat te swaar is om te dra nie. } \\
\text { [Through the pain in my heart, I thank God for this day, for my life, } \\
\text { for my children that look up to me. My aunt has been murdered. } \\
\text { And I do not want to question God. I know that He will never give } \\
\text { me a cross that is too hard to bear.] }\end{array}$ & $\begin{array}{l}\text { Negative authorial affect coupled with } \\
\text { positive affect, as well as non-authorial } \\
\text { affect in the responses of the children. } \\
\text { Note also the intertextual attribution to } \\
\text { God in the last sentence. }\end{array}$ \\
\hline $\begin{array}{l}\text { W3: Ek voel baie ongelukkig vandag omdat my man my baie } \\
\text { afkraak. [l feel very sad today because my husband often } \\
\text { belittles me.] }\end{array}$ & $\begin{array}{l}\text { Negative affect, amplified coupled with } \\
\text { negative non-authorial attribution to } \\
\text { spouse. }\end{array}$ \\
\hline $\begin{array}{l}\text { W11: As ek by die huis is dink ek alle dinge. Ek wou eenkeer my } \\
\text { eie lewe neem so swaar dit met my en my kind was .... [When I'm } \\
\text { at home, I think all sorts of things. Once, I wanted to take my own } \\
\text { life, that's how badly it went with my son and me.] }\end{array}$ & Negative affect, amplified. \\
\hline
\end{tabular}

In the examples above, we find intertextual attribution to God and an unsympathetic husband. These examples are also all dialogistic in nature and assume a dialogue with either God and/or the person reading the journal.

In the first three examples, the women express themselves and their Christian identity mainly in the first person ('ek' [I]) and occasionally in the second person ('jou' [you]), as can be expected when writing an individual journal. They are therefore expressing their individual voice and religious ideology, belief, and experience instead of what Blommaert (2005: 181) calls 'massive and rock-solid universal-humanist principles.' In the extract quoting $\mathrm{W}_{5}$, she remains grateful to God, despite experiencing the terrible loss of her murdered aunt. Of interest here is her strong reliance on her faith and an acceptance of the 'cross' placed on her shoulders. It is also a matter of pride to her that her children look up to her. It could be argued that, in conditions of dire poverty, women who have been let down and marginalised by human agencies such as government naturally look to a 
higher power to give them strength and comfort to face their daily struggles. Writing about their faith also self-identified them as decent, God-fearing women deserving of respect.

Judgement, as was previously noted, involves either positive or negative evaluations of human behaviour. For White (Appraisal website/judgement) the analysis of judgement must take account of both explicit and implicit judgement. Implicit judgement can be carried by unevaluated facts, such as the simple statement in the first entry of Table 2 by W1:'Hulle was finansiel swak' [They were too poor]. Explicit judgement is usually indicated by lexical items that carry the judgement value. We can see explicit judgement in all the other examples listed in Table 2, for example: 'bitter kwaad' [very angry], 'slat my blou ö̈' [hits me, giving me blackened eyes], and 'besig om my te intimideer' [is intimidating me]. In addition to the extra-vocalisation from the boyfriend by W13, who uses his direct words in her writing, these lexical items have the potential to evoke negative Judgement in the reader as well.

The above examples represent the reality for most of these women - trapped in poverty and frequently subjected to crime and violence, with unsupportive partners and parents who were too poor to provide them with a good education. The example from W11 shows how family violence is part of the recurrent cycle of poverty for these women. They have grown up in houses where such violence was common, and now they experience it themselves. Abusive and unsympathetic partners are powerful figures in the lives of these women, coupled with a lack of support in running the household and helping with the children. Two women dropped out of the course after the first week because their partners objected to them attending the course. Those who persevered, like W2, often had to deal with negative comments at home. The sometimes startling honesty with which these women unburden themselves shows that they are fully capable of using their own voice (Blommaert, 2005) by drawing on the discursive means they have at their disposal.

While 'appreciation' is most commonly concerned with aesthetics, White and his fellow researchers (Appraisal website/appreciation) also include positive and negative assessments of processes and states of affairs under this subcategory of attitude. The three examples in Table 3 all reveal appreciation of the training course and particular elements of the course. The course appears to have been a very positive experience for most of the women and a welcome break from their daily lives. This was in fact the only aspect singled out by them for positive appreciation, which could be another indication of the harshness of their lives. 
Table 2: Examples of judgement

W8: My ouers kon my nie help met geld vir universiteit nie. Want ek wou graag verder studier het maar finansies was nie daar nie. Hulle was finansiel swak. [My parents could not help with money for university. Because I really wanted to study further but the finances weren't there. They were financially disadvantaged.]

W4: My ma is bitter kwaad vir my omdat ek is waar ek vandag is. Dit maak my baie ontevrede omdat sy kwaad is vir my. [My mother is furious with me because I am where I am today. It upsets me a lot because she is angry at me.]

W11:... ek kom uit so 'n huis waar my ouers so beklei het en ek voel so 'n lewe is nie vir my nie. Nie net vir my nie maar is onregverdig teenoor my kind. [I was raised in a house where my parents always used to fight and I feel that a life like that is not for me. Not only for me, but it's also unfair towards my child.]

W13: ... nou begin hy met my kind skel, sê ek sal nie kos koop nie want jy is nie my kind nie nou gee ek miskien antwoord dan slat hy my blou oë slat my met hamers en slat my kind .... [... now he starts to scold my child, saying I won't buy food because you are not my child; and if I maybe give an answer then he hits me leaving me with blackened eyes. He uses hammers to beat me and he hits my child ....]

W2: Ek voel my man is besig om my te intimideer en ek het elke keer toegelaat dat hy dit doen. Hy kry dit reg om my skuldig te laat voel, maar ek weet dat ek moet deurdruk met waarmee ek begin het. [I feel that my husband is intimidating me and I have allowed him to do it every time. He manages to make me feel guilty, but I know that I must persevere with what I have begun.]
Implicit negative judgement of parents' poverty.

Non-authorial as well as authorial affect, coupled with non-authorial (the mother's) as well as authorial explicit judgement.

Explicit negative judgement and negative affect attributed to parents.

Explicit negative judgement of boyfriend's violent behaviour coupled with inserted extra-vocalisation/inter-textual positioning from the boyfriend (in bold font).

Explicit negative judgement of spouse's intimidating behaviour.

Table 3: Examples of appreciation

W5: Ek geniet dit om 'n student van Bergzicht te kan wees.

[I enjoy being a student at Bergzicht.]

W7: Soggens kan ek nie wag om by Bergzicht uit te kom nie want ek vind dit so intresant. [In the mornings, I can't wait to get to

Bergzicht because I find it so interesting.]

W11: Dit was 'n lekker dag maar ek het weereens baie geleer hoe ' $n$ wasmasjien en droer te behandel. Ek was baie beindruk met die nuwe lesse. [It was a nice day but again I learnt so many things like how to use a washing machine and a dryer. I was very impressed with the new lesson.]
Positive evaluation of studying at

Bergzicht, where the course took place.

Positive evaluation of the course.

Positive evaluation of the lessons.

\section{Engagement and dialogistic positioning}

White (Appraisal website/engagement) sees engagement as the ways in which the writers 'adjust and negotiate the arguability of their utterances', and he further contends that all utterances that can be classified as engagement are 'dialogistic' in nature, as the speakers or writers 'present themselves as taking up, acknowledging, responding to, challenging or rejecting actual or imagined prior utterances'. The examples in Table 4 can all be seen as attempts by the women to 'talk back to' or challenge particular assumptions, persons, or groups. 
Some of the key engagement resources as listed by White (Appraisal website/engagement) are used by the women quoted in Table 4 . These are:

- proclamation, including expectation and pronouncement - these are formulations that challenge any contradictions, like the expectations of W6

- disclamation, including counter-expectation - the introduction of alternative positions in an assumed dialogue, as with $\mathrm{W}_{5}$

- probabilisation, including evidence, likelihood, and hearsay - these are possible points of contention the writer wants to point out, as with W4.

$\mathrm{W}_{7}$ did not allow the negative perceptions of her by the rest of the group to divert her from working hard on the course. Despite the social power of the group as a whole, which could intimidate some women, she did not allow any negativity from the group to influence her. W5 was planning to use her new qualification to look for work beyond domestic service, which is an indication of her ability to decide for herself what she wants to do with what she has gained from the course, instead of just following the expected outcome of doing domestic work. Although the course elicited appreciation from most of the participants, W4 was critical of the communications facilitator who asked them to share some of their journal entries with each other at the start of one session. She clearly felt that some deeply personal issues should not be shared with others.

Table 4: Examples of engagement

W7: Het geleer om daardie ekstra myl te loop. Al dink die ander ek soek witvoetjie. [(I) have learned to walk that extra mile. Even though the others think that I am trying to curry favour with the facilitators.]

W5: Ek wil nie eintlik'n domestic wees nie. Met die sertifikaat kan ek op my eie 'n werk soek in 'n factory. [I don't actually want to be a domestic worker. With the certificate I can find a job in a factory on my own.]

W2: Die Kursus is so te sê klaar. Ek het dit geniet ongeag my probleempies wat tussenbeide getree het. Ek bly positief. [The course is almost finished. I really enjoyed it despite my little problems which interfered with it. I stay positive.]

W6: Ek wil graag 'n goeie inkoms hê sodat ek onafhanglik van my man kan wees. 'n Mens wil baie keer iets gaan koop dan moet jy maar los, want jy moet eers alles vra. [I would really like to have a good income so that I can be independent from my husband. Many times, you will want to buy something but then you must rather leave it because you must ask for everything.]

W4: Dit is nie altyd goed om jouself aan ander mense te open nie. Som kan baie negatief wees, en baie weer sensitief. [It isn't always good to open yourself to other people. Some can be very negative, and others very sensitive.]
Proclamation: Pronouncement of improved ability plus attribution and extra-vocalisation of the thoughts/negative perceptions of others.

Disclamation: Counter-expectation of course qualifications.

Proclamation: Pronouncement modified by reference to 'little problems'.

Proclamation: Expectation that course can change the life of the writer, providing her with independence from her husband and the freedom to buy what she wants.

Proclamation: Pronouncement coupled with probabilisation - the likely negative effects of opening up to others (in this case, via sharing their journal entries with one another). 
A strong sense of personal agency (Labelle, 2011) is present in these extracts, which show that these women were doing their best to remain positive even though they faced many difficulties. W2 appears determined to minimise her problems by referring to them in the diminutive form ('probleempies' [teeny problems]) and trying to stay positive. The women wanted to gain skills through this training so that they could provide better for their children and also accomplish and establish a sense of independence for themselves. They longed, like W6, for the luxury of not having to rely on someone else for money or food and to have some control over their own lives, moving from a situation of disempowerment to empowerment.

\section{Conclusion}

Through an Appraisal analysis of the journals of 13 women, this paper has revealed the ways in which these women express emotion, voice, and agency through the act of writing and reflecting on their experiences during a training course for domestic workers. The paper also attempted to uncover those recurrent discourses and attitudes which appeared to empower or disempower the women from becoming effective agents capable of challenging their positions in their families and society. Their micro-discourses have shown that the key issues affecting their lives include being trapped in the poverty cycle, feeling trapped by their personal circumstances, which include abusive and unsupportive partners, and a desire for greater economic independence. Their faith in God was also a constant refrain throughout their journal entries.

The group of women studied in this paper were all working class individuals who were trying to improve their living conditions. Their journal writing within the context of a more enabling space gave them the opportunity to respond to both the positive, empowering forces and the disempowering forces in their lives, by giving them a channel for self-expression. The application of Appraisal analysis provided us with evidence of strong agency and voice coming through in certain entries, but we also noted that such confidence could, with the same respondents, slip back into depression and a sense of being overwhelmed in some of the entries that followed. However, every woman's journal ended very positively at the end of the course - either because they wanted to impress their facilitators or because there had really been a positive change in the way they viewed themselves.

The practice of writing a journal was clearly empowering, not simply as a means of practising a literacy skill, but also because it provided the women with the opportunity 'to produce a lasting, consequential, thoughtful discourse artefact' (Blommaert, 2005: 96). A common thread throughout the journals was that this course could be a lifeline to empowering themselves as strong, independent working women. Although there are a number of exceptions, such as the women who dropped out of the course, these journals on the whole embody their transformation from a disempowered position to a more empowered position with the aid of the course. While we would argue that, in some cases, the effects only lasted for a short while, in other cases, the effects were much more lasting. 
Proof of this is that of the women surveyed here, eight gained meaningful employment after completing the course, while conditions for the other five women remained unchanged when we did a follow-up study on them six months later.

Taken as a whole, we contend that some of these women were perhaps already active, participatory citizens before attending the course, but that the course had improved their sense of agency while helping the more submissive participants to realise their own strength to some extent and to challenge, or at least begin to question, the existing power structures in their lives through the act of journal writing.

Acknowledgement - We wish to acknowledge the generous funding of the National Research Foundation (NRF) which paid for the studies of two of the authors as part of the research project 'Township women's discourses and literacies'.

\section{Note}

1 Charlyn Dyers is an associate professor in the Department of Linguistics, University of the Western Cape, while Meggan Williams and Tatum Barthus are in the process of completing their MA degrees in the department. 


\section{References}

Achmat F \& Losch A. 2002. Wesbank: Power is the name of the game ... Power is the name of the problem. In Davids I (ed.) Good governance and community participation: Case studies from the Western Cape. Cape Town: Foundation for Contemporary Research, 12-35. Altarriba J. 2005. Cognitive approaches to the study of emotion-laden and emotion words in monolingual and bilingual memory. In Pavlenko A (ed.) Bilingual minds, emotional experience, expression and representation. Clevedon: Multilingual Matters, pp 232-256.

Baynham M \& De Fina A. (eds) 2005. Dislocations/relocations: Narratives of displacement. Manchester: St. Jerome Publishing.

Blommaert J. 2005. Discourse: Key topics in sociolinguistics. Cambridge: Cambridge University Press.

Blommaert J, Muyllaert N, Huysmans M \& Dyers C. 2005. Peripheral normativity: Literacy and the production of locality in a South African township school. Linguistics and Education 16(4): 378-403.

Dyers C. 2004. Ten years of democracy: Attitudes and identity among some South African school children. Per Linguam 2o(1): 22-35.

Dyers C. 2008. Language shift or maintenance? Factors determining the use of the Afrikaans language among some township youth in South Africa. Stellenbosch Papers in Linguistics (SPIL) 38: 49-72.

Hernandez-Zamora G. 2010. Decolonizing literacy. Mexican lives in the era of global capitalism.

Bristol: Multilingual Matters.

Jones K, Martin-Jones M \& Bhatt A. 2000.Constructing a critical, dialogic approach to research on multilingual literacy: Participant diaries and diary interviews. In MartinJones M \& Jones K (eds) Multilingual literacies: Reading and writing different worlds. Amsterdam/Philadelphia: John Benjamins, pp 319-352.

Joncker G \& Newton C. 2004. The Cape Flats: An urban strategy for poverty alleviation. Unpublished MA thesis, St Lucas Institute, Ghent.

Labelle S. 2011. Language and identity. In Mooney A, Stilwell Peccei J, Labelle S, Henriksen B, Eppler E, Irwin A, Pichler P, Preece S \& Soden S (eds) Language, society and power: An introduction. Oxford: Routledge, pp 173-199.

Martin J. 1997. Analysing genre: Functional parameters. In Christie F \& Martin J (eds) Genres and institutions: Social processes in the workplace and school. London: Cassell, pp 3-39.

Martin J. 2000. Beyond exchange: APPRAISAL systems in English. In Hunston S \& Thompson G (eds) Evaluation in text: Authorial stance and the construction of discourse. Oxford: Oxford University Press, pp 142-175.

Martin JR \& Rose D. 2007. Working with Discourse: Meaning beyond the clause. London \& New York: Continuum.

Moola Z. 2002. Poverty alleviation strategies: A critical overview of the City of Cape Town's socio-economic policies with specific reference to the Wesbank area. Cape Town: Foundation for Contemporary Research. 
Pavlenko A. 2005. Bilingual selves. In Pavlenko A (ed.) Bilingual minds: Emotional experience, expression and representation. Clevedon: Multilingual Matters, pp 1-33.

Pavlenko A. (ed.) 2011. Thinking and speaking in two languages. Bristol: Multilingual Matters.

Slemming F. 2010. An Exploration of the link between selected women's discourses and literacy resources in the working class township settlement of Wesbank, South Africa. Unpublished MA thesis, University of the Western Cape.

Statistics South Africa. 2011. Quarterly labour force survey 2011. Pretoria: Statistics South Africa.

Stroud C. 2009. Response to Blommaert: Language, asylum and the national order. Current Anthropology 50(4): 434-435.

Sutton M. 2008. Knowledge citizenship for active informed citizenship. South African Journal of Information Management 10(4): 1-5.

Van der Merwe IJ \& Van der Merwe JH. 2006. Linguistic Atlas of South Africa: Language in Space and Time. Stellenbosch: SUN Press.

Weiss B. 2004. Tangible voice-throwing: Empowering corporeal discourses in African women's writing of southern Africa. Germany: Peter Lang.

Williams G. 2010. The knowledge economy, language and culture. Bristol: Multilingual Matters.

White P. n.d. The Appraisal website. Available at http://grammatics.com/appraisal/ [accessed 21 November 2011].

White P. 1998. Telling media tales: The news story as rhetoric. PhD dissertation, University of Sydney.

White P. 2000. Dialogue and inter-subjectivity: Reinterpreting the semantics of modality and hedging. In Coulthard M, Cotterill $\mathrm{J}$ \& Rock F (eds) Working with dialogue. Berlin: Max Niemeyer

Verlag, pp 67-80. 